\title{
Implementasi Aplikasi Web Full Stack Pendataan Cloversy.id
}

\author{
Eric Prima Wijaya ${ }^{[1]}$, Sandy Kosasi ${ }^{[2]}$, David ${ }^{[3]}$ \\ Teknik Informatika ${ }^{[1],[3]}$, Sistem Informasi ${ }^{[2]}$ \\ STMIK Pontianak \\ Pontianak, Indonesia \\ ericprimaw@stmikpontianak.ac.id ${ }^{[1]}$,sandykosasi@stmikpontianak.ac.id ${ }^{[2]}$, david@ stmikpontianak.ac.id ${ }^{[3]}$
}

\begin{abstract}
Data collection has a big impact on the growth and effectiveness of business processes. Data collection done using manual methods can cause various obstacles, such as difficulty in accessing information, limited access, and the process of tracing history which takes a lot of time. Cloversy.id is an online shop operate in painting service. The data collection system that currently used by Cloversy.id has problems, where the Cloversy.id team has difficulty to serve consumers because it is difficult to access sales information. Information collection is done by taking notes on paper and using Google Sheets so that the data has an inconsistent format and is difficult to search through. The purpose of this research is to produce a data collection application that can be used by Cloversy.id to manage data collection including financial management, products, vendors, and jobs. The data used is factual data from Cloversy.id including financial data, products, vendors, and job listings. This research is case study research. The application development method uses the Extreme Programming approach with the stages of planning, designing, implementing, and testing. The result of this research is a full stack data collection web application built with Node.js, Express, Ejs and MongoDB as the main technology. The Extreme Programming method applied is able to produce applications that run well and have functions that suit their needs. With this data collection application, the problems experienced by Cloversy.id are resolved because the application can be used to quickly manage and collect various types of data. Testing the application with a black box shows the application is functioning properly.
\end{abstract}

Keywords- Web Application, Full Stack, Extreme Programming, Unified Modeling Language

Abstrak - Pendataan memiliki pengaruh yang besar dalam kelancaran dan keefektifan proses usaha. Pendataan yang dilakukan dengan metode manual dapat menimbulkan berbagai kendala seperti sulitnya akses terhadap informasi, keterbatasan akses, dan proses penelusuran histori yang memerlukan banyak waktu. Cloversy.id merupakan toko online yang bergerak dibidang seni lukis. Sistem pendataan yang digunakan Cloversy.id memiliki kendala, dimana tim Cloversy.id kesulitan saat ingin melayani konsumen dikarenakan sulit untuk mengakses informasi penjualan. Pendataan informasi dilakukan dengan cara mencatat pada kertas dan menggunakan Google Spreadsheet sehingga data memiliki format yang tidak konsisten dan sulit dicari. Tujuan dari penelitian ini adalah menghasilkan aplikasi pendataan yang dapat dipergunakan Cloversy.id untuk mengelola pendataan mencakup pengelolaan keuangan, produk, vendor, dan pekerjaan. Data yang digunakan merupakan data faktual dari Cloversy.id mencakup data keuangan, produk, vendor, dan daftar pekerjaan. Penelitian ini merupakan penelitian studi kasus. Metode pengembangan aplikasi menggunakan pendekatan Extreme Programming dengan tahapan perencanaan, perancangan, implementasi, dan pengujian. Hasil dari penelitian ini adalah aplikasi web pendataan full stack yang dibangun dengan Node.js, Express, Ejs dan MongoDB sebagai teknologi utama. Metode Extreme Programming yang diterapkan mampu menghasilkan aplikasi yang berjalan dengan baik dan memiliki fungsi yang sesuai dengan kebutuhan. Dengan aplikasi pendataan ini, kendala yang dialami Cloversy.id teratasi karena aplikasi dapat digunakan untuk mengelola dan mberbagai jenis pendataan dengan cepat. Pengujian aplikasi dengan black box menunjukkan aplikasi berfungsi dengan baik.

Kata Kunci-Aplikasi web, Full Stack, Extreme Programming, Unified Modeling Language

\section{PENDAHULUAN}

Pendataan merupakan faktor penting dalam menjalankan suatu usaha, metode pendataan dapat mempengaruhi kelancaran akses pemilik usaha terhadap informasi. Sulitnya akses terhadap informasi dapat menghambat proses usaha, seperti kegiatan penjualan yang umumnya membutuhkan referensi ke histori transaksi yang dikumpulkan dari proses pendataan.

Informasi adalah data yang telah diproses sedemikian rupa, informasi merupakan pengetahuan dan dapat menjadi manfaat bagi suatu usaha serta menjadi bahan pertimbangan pengambilan keputusan [1][2]. Cara pengolahan pendataan yang tidak efektif akan berdampak pada efektifitas kerja menjadi rendah dan membutuhkan banyak waktu dan tenaga [3]. Oleh karena itu, usaha membutuhkan metode pendataan dan yang baik untuk meningkatkan efektifitas dalam proses usaha.

Cloversy.id merupakan sebuah toko berbasis online yang bergerak dibidang seni khususnya jasa lukis (custom painting). Cloversy.id menyediakan solusi untuk masyarakat yang ingin tampil unik dan beda, atau sebatas ingin menuangkan inspirasi atau bahkan cerita kedalam bentuk karya seni lukisan dengan media seperti sepatu, tas, dompet, atau benda lain berbahan kanvas dan kulit.

Sistem adalah suatu susunan atau jaringan kerja dengan prosedur yang jelas dan berhubungan untuk mencapai suatu sasaran atau tujuan tertentu [4]. Suatu sistem digunakan untuk

$$
\text { p-ISSN 2301-7988, e-ISSN 2581-0588 }
$$

DOI : $10.32736 /$ sisfokom.v10i3.1293, Copyright (C2020

Submitted : October 11, 2021; Revised : November 5, 2021; Accepted : November 15, 2021; Published : November 29, 2021 
membantu dan memudahkan pekerjaan, termasuk sistem pendataan yang mendukung dalam melakukan pendataan dan pencarian kembali informasi.

Sistem pendataan yang sedang digunakan di Cloversy.id untuk pendataan informasi penjualan masih merupakan sistem pendataan manual dengan menggunakan kertas dibantu dengan dukungan aplikasi Google Spreadsheet dan sistem folder. Pendataan yang dilakukan diantaranya pendataan pengeluaran, pemasukan, katalog desain dan daftar pekerjaan. Dengan digunakannya sistem pendataan manual, kendala yang sering muncul pada waktu melakukan pengecekkan histori dan melakukan pembukuan. Kendala yang didapati adalah format pendataan tidak konsisten. Informasi sulit diakses karena harus mencari secara manual disaat menentukan harga berdasarkan histori, katalog design yang sulit diakses informasinya baik detail harga maupun detail desain.

Sulitnya akses terhadap informasi sering menghambat pemilik toko dalam menjawab pertanyaan terkait harga dan desain dari customer. Selain itu, pemilik toko juga tidak dapat melakukan kustomisasi fungsi sesuai kebutuhan, mengintegrasikan antara pengeluaran dan pemasukan. Sistem manual yang digunakan menjadi salah satu faktor keterlambatan dalam hal pelayanan transaksi [5]. Kendalakendala tersebut menyebabkan sistem pendataan menjadi tidak efektif dan mengakibatkan tim Cloversy.id harus bekerja ekstra untuk menyelesaikan pekerjaan yang sebenarnya dapat diselesaikan dengan lebih cepat dan efektif.

Untuk mengurangi kendala dan meningkatkan efektivitas Cloversy.id dalam melakukan pendataan. Diperlukan sebuah aplikasi dalam mendukung proses pendataan pemasukan, pengeluaran, katalog desain, dan daftar pekerjaan.

Aplikasi adalah program yang sudah dirancang sedemikian rupa dan siap dipakai untuk melaksanakan suatu fungsi untuk pengguna atau aplikasi yang lain [6]. Salah satu jenis aplikasi yang sering digunakan adalah aplikasi web. Aplikasi web adalah sebuah sistem informasi yang mendukung interaksi pengguna melalui antarmuka berbasis web. Aplikasi web merupakan sebuah aplikasi yang dapat diakses melalui internet [7]. Aplikasi web banyak digunakan dikarenakan memiliki ketangguhan dalam hal fleksibilitas akses, aplikasi web modern didesain untuk dapat diakses dari berbagai jenis perangakat yang berbeda (baik desktop ataupun mobile).

Aplikasi web dapat digunakan diberbagai sistem operasi secara langsung selama terdapat jaringan internet tanpa harus dilakukan instalasi terlebih dahulu [8]. Aplikasi web memiliki kompabilitas yang tinggi dan mudah disesuaikan, hal ini dikarenakan aplikasi web berjalan dan diproses oleh web browser [9].

Kriteria dan kelebihan yang dimiliki oleh aplikasi web cocok dengan kebutuhan Cloversy.id mengingat sistem kerja yang digunakan sangat bergantung pada divisi- divisi tim yang ada dalam Cloversy.id. Tim-tim tersebut membutuhkan akses terhadap aplikasi untuk melakukan pendataan ataupun untuk memulai pekerjaan dengan melihat detail pekerjaan secara mudah menggunakan smartphone maupun desktop. Sesuai dengan kebutuhan, aplikasi yang akan dirancang dan diterapkan untuk mengatasi permasalahan yang ada pada Cloversy.id merupakan suatu aplikasi web dengan harapan dapat menyelesaikan masalah yang dialami dalam proses pendataan pada saat masih menggunakan sistem lama. Fungsi yang terdapat pada aplikasi adalah pendataan penjualan, pembelian, katalog desain, dan manajemen daftar pekerjaan

Pada penelitian- penelitian sebelumnya, pengembangan aplikasi web pada kasus dan arsitektur sistem serupa cenderung menggunakan bahasa pemrograman PHP sebagai bahasa pemrograman utama fondasi aplikasi, serta penggunaan database sequel database MySQL [10][11][12]. Pada penelitian ini, Javascript merupakan satu- satunya bahasa pemrograman yang akan digunakan baik untuk front-end maupun back-end serta menggunakan database non sequel MongoDB, ditambah aplikasi yang dibangun memanfaatkan penyimpanan berbasis cloud baik dari segi database yang menggunakan MongoDB Atlas maupun penyimpanan media Cloudinary.

\section{METODE PENELITIAN}

Penelitian ini merupakan penelitian studi kasus. Studi kasus adalah uraian dan penjelasan komprehensif mengenai berbagai aspek seorang individu, suatu kelompok, organisasi, suatu program, atau suatu situasi social [13]. Data dikumpulkan dengan dilakukannya wawancara dengan melakukan tanya jawab dengan pengguna yang merupakan bagian dari tim Cloversy.id. Sumber data yang akan dipakai dalam proses pendataan dan yang kemudian akan diolah menggunakan aplikasi didapatkan secara langsung dari Cloversy.id yang merupakan data faktual yang digunakan dari tahun 2020 hingga 2021. Data mencakup data pemasukan, pengeluaran, katalog desain, daftar pekerjaan, vendor dan data konsumen.

Penelitian ini akan menghasilkan sebuah aplikasi web untuk keperluan pendataan Cloversy.id dengan fitur utama pendataan pengeluaran, pemasukan, katalog desain dan vendor. Aplikasi web pendataan tersebut akan dikembangkan dengan pendekatan extreme programming. Extreme programing adalah salah satu turunan dari metode Agile development yang digunakan untuk melakukan pengembangan perangkat lunak secara cepat dan terbuka dengan melibatkan pengguna dalam proses pengembangan [14]. Aplikasi dikembangkan dengan melibatkan pengguna dari aplikasi selama proses pengembangan berlangsung, pengembangan aplikasi akan berfokus pada kebutuhan dan fungsi utama aplikasi sebagai sistem pendataan yang baru. 


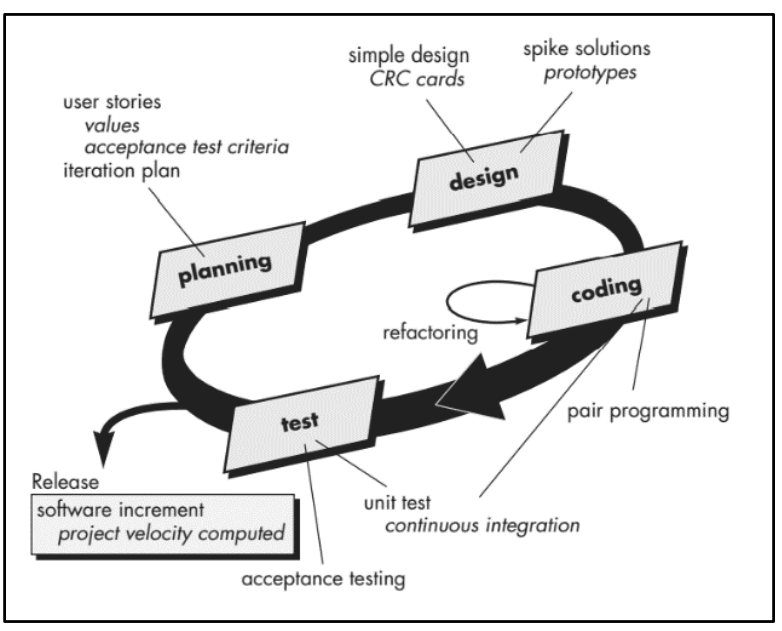

Gambar 1. Tahapan Extreme Programming [15]:

Tahapan dari extreme programming dibagi menjadi 4 yaitu

\section{1) Planning (Perencanaan)}

Tahapan perencanaan merupakan langkah pertama sebelum membangun sistem. Dalam penelitian ini dilakukan perencanaan terkait aplikasi web yang mau dikembangkan, arsitektur yang akan digunakan, dan fitur yang dibutuhkan.

\section{2) Design (Perancangan)}

Pada tahapan perancangan akan dilakukan pemodelan sistem dan pemodelan arsitektur. Pemodelan dilakukan berdasarkan hasil analisis spesifikasi dan user stories. Pemodelan sistem menggunakan Unified Modelling Language (UML).

\section{3) Coding (Pengkodean)}

Tahapan ini merupakan tahapan penerapan dan realisasi. Model dan spesifikasi yang sudah dibuat digunakan sebagai pedoman untuk dibuat kedalam bentuk kode sistem untuk menghasilkan aplikasi web pendataan Clovesry.id.

\section{4) Testing (Pengujian)}

Merupakan tahapan terakhir dari siklus utama extreme programming. dimana akan dilakukan pengujian terhadap aplikasi yang sudah dikembangkan. Pengujian menentukan apakah aplikasi dapat berfungsi dengan baik.

Pemodelan sistem menggunakan UML (Unified Modeling Language). Aplikasi web pendataan Cloversy.id dibangun menggunakan dari bahasa pemrograman Javascript dibantu dengan beberapa teknologi web full stack, yaitu:
A. Node.js

Merupakan runtime untuk membangun dan menjalankan aplikasi web diluar web browser dengan menggunakan bahasa pemrograman Javascript [16]. Node.js juga menyediakan berbagai jenis modul dengan berbagai fungsi yang dapat digunakan dalam pengembangan aplikasi [16][17]. Dalam penelitian ini, terdapat beberapa modul Node.js yang akan digunakan seperti Express.js, Passport, Mongoose, Multer, Helmet, dan lainnya.

B. Express

Framework dan modul yang disediakan oleh Node.js yang berfungsi untuk melakukan perancangan sistem dan logika back-end pada aplikasi ini. Express memilik banyak fitur yang sangat membantu dalam melakukan request ke server [18].

C. EJS

Merupakan bahasa templating untuk menghasilkan markup HTML dengan Javascript. Penggunaan EJS membantu dalam melakukan pembuatan markup dengan data yang dinamis.

\section{MongoDB}

NoSQL Database berbasis document-oriented. MongoDB dapat digunakan untuk menyimpan berbagai data dalam bentuk menyerupai JSON dengan sangat fleksibel [19].

\section{HASIL DAN PEMBAHASAN}

\section{1) Planning (Perencanaan)}

Perencanaan aplikasi web pendataan Cloversy.id dengan menggunakan User Stories berdasarkan hasil wawancara kepada tim Cloversy.id sehingga terlihat hak akses dan kebutuhan sistem pada setiap tingkat user, dapat dilihat pada Tabel 1.

TABEL I. USER STORIES

\begin{tabular}{|c|l|}
\hline \multicolumn{1}{|c|}{ User } & \multicolumn{1}{|c|}{ Kebutuhan Sistem } \\
\hline \multirow{3}{*}{ Admin } & $\begin{array}{l}\text { Admin adalah pemilik hak akses tertinggi yang } \\
\text { menambahkan user baru, mengontrol data } \\
\text { pemasukan, pengeluaran dan kas, mengontrol data } \\
\text { katalog desain, mengontrol data vendor, dan } \\
\text { mengontrol data daftar pekerjaan. }\end{array}$ \\
\hline Non-Admin & $\begin{array}{l}\text { kon-Admin adalah user yang mengakses data } \\
\text { kekerjaan. Dalam penggunaannya, user non-admin } \\
\text { memiliki role yang disebut sebagai Painter, } \\
\text { Designer, dan Seller. }\end{array}$ \\
\hline
\end{tabular}

Arsitektur sistem menggambarkan bagaimana proses kerja aplikasi yan dirancang bekerja secara keseluruhan, Arsitektur perancangan aplikasi web pendataan Cloversy.id ditunjukkan pada Gambar 1. 


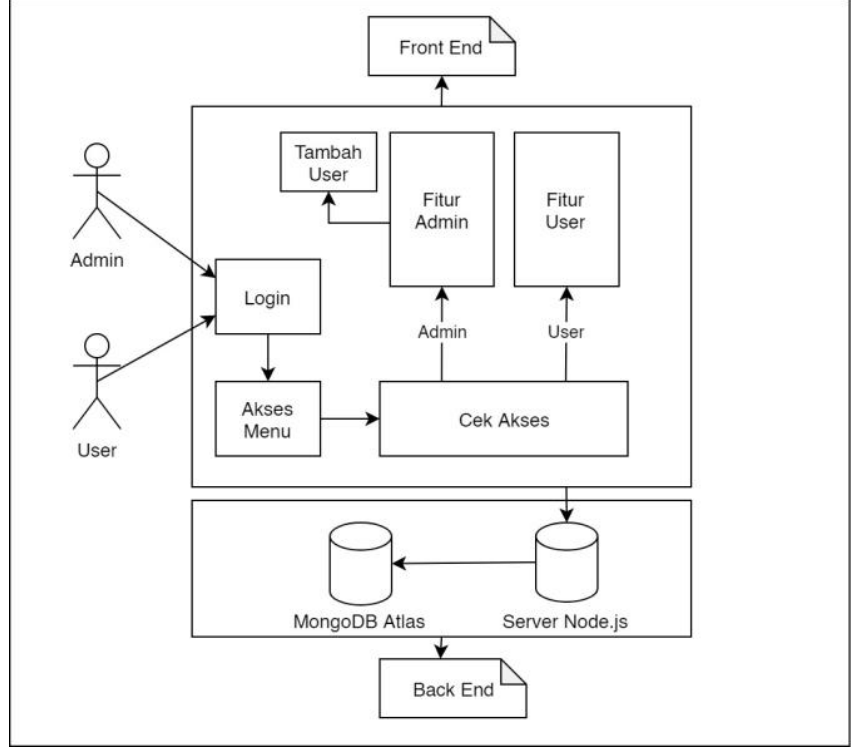

Gambar 2. Arsitektur Sistem

Pada arsitektur tersebut, client atau user mengakses frontend landing page dan melakukan request login untuk dapat mengakses fitur- fitur yang ada. Request akan dikirimkan ke server dan diproses terintegrasi dengan database. Pada saat response dikembalikan page akan diarahkan ke bagian dashboard untuk kemudian client dapat melakukan akses sesuai batasan hak akses akun.

Penggunaan database pada aplikasi ini menggunakan MongoDB Atlas yang merupakan cloud based Database Management System (DBMS) yang menggunakan konsep NoSQL terfokus dengan data yang tidak terstruktur [19]. Setiap fitur dioperasikan, akan mengirim kembali request untuk mendapatkan atau mengirimkan data dari backend agar dapat ditampilkan, dimodifikasi, dihapus atau membuat data baru.

\section{2) Design (Perancangan)}

Alur penggunaan aplikasi dijelaskan dalam diagram use case. Fungsi admin dalam penggunaan aplikasi adalah saat berhasil melakukan autentikasi dan login, admin dapat melakukan berbagai aktivitas seperti mengelola pemasukan dan pengeluaran dengan menambahkan, mengubah, mengakses, atau menghapus data. Admin dapat mengelola katalog produk dengan detail foto, harga, dan deskripsi produk, mengelola daftar pekerjaan, serta mengelola data vendor yang dimiliki.

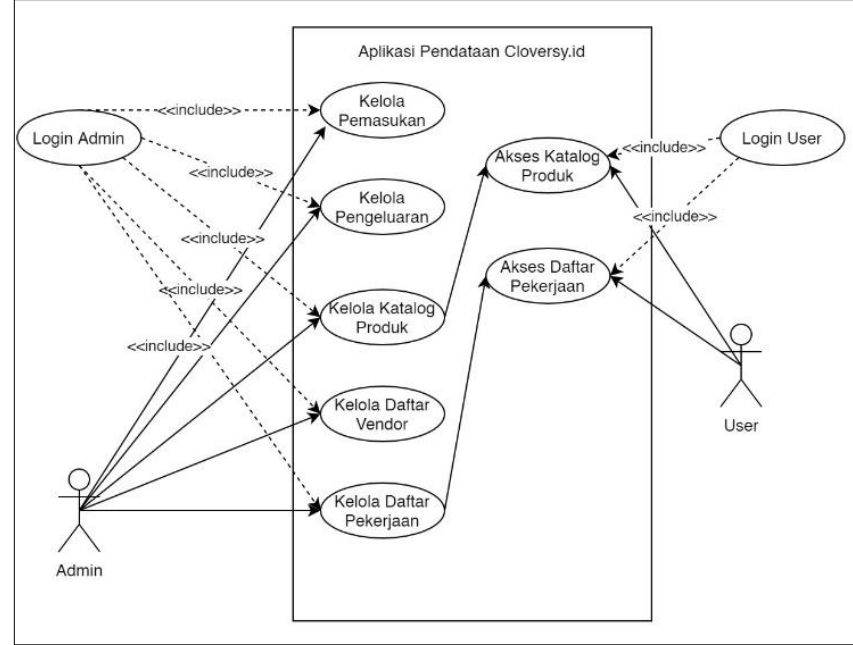

Gambar 3. Use Case Diagram

Untuk menggambarkan berbagai alur aktivitas dalam sistem, proses bagaimana suatu aktivitas didalam sistem dilakukan, cara kerja sistem diuraikan dalam diagram activity. Pengelolaan data pengeluaran yang dilakukan admin diawali dengan pemilihan fitur keuangan, yaitu terdapat pilihan pemasukan atau pengeluaran. Setelah menentukan pilihan pengeluaran, daftar pengeluaran akan muncul lengkap dengan data yang diambil dari database.

Pada daftar tersebut, admin dapat menambahkan data pengeluaran baru atau mengakses detail setiap item. Apabila admin ingin menambahkan data baru maka form data baru akan ditampilkan. Admin mengisikan data sesuai dengan form. Setelah data terisi dengan lengkap, maka admin mengklik tombol simpan dan proses penambahan data baru selesai. Apabila admin ingin mengakses detail data dari daftar, admin mengklik nama dari daftar. Setelah nama item diklik, sistem akan menampilkan detail dari item yang diklik. Pada halaman detail item pengeluaran atau pemasukan, admin dapat menghapus, mengubah data detail.

Jika admin ingin mengubah data, form edit akan ditampilkan dengan data yang sudah ada, admin mengisi data yang baru, dan mengklik tombol simpan, data yang lama akan diperbaharui dengan data yang baru dan proses mengubah data selesai. Apabila admin ingin menghapus data, admin mengklik tombol hapus pada detail item, dan melakukan konfirmasi penghapusan data, setelah disetujui, data akan dihapus dan admin akan dikembalikan ke halaman daftar pengeluaran. 


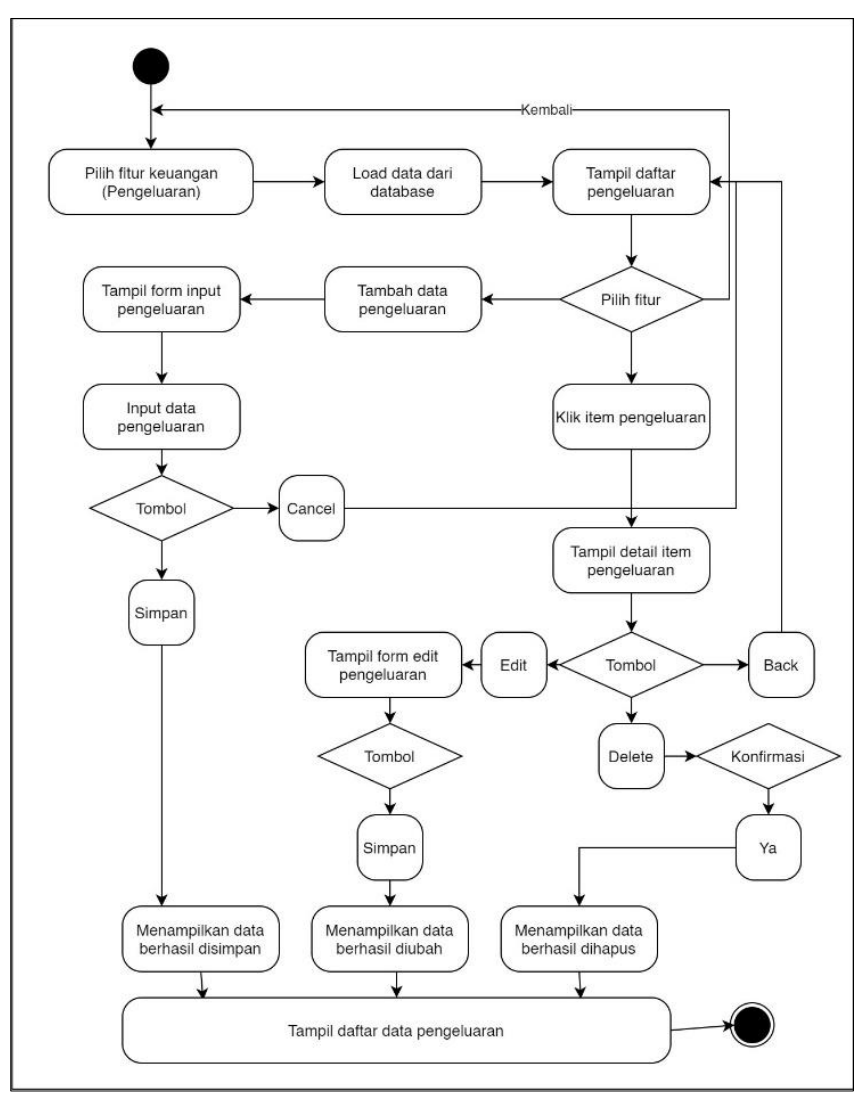

Gambar 4. Activity Diagram Pengelolaan Data Pengeluaran

Untuk pengelolaan data pemasukan, memiliki alur yang sama dengan pengelolaan data pengeluaran. Diawali dengan admin mengakses daftar pemasukan, terdapat pilihan untuk menambahkan data pemasukan baru, dan melihat detail item pemasukan.

Untuk menambahkan data pemasukan baru, sistem akan mengarahkan ke form input pemasukan, apabila simpan maka data pemasukan akan diteruskan ke sistem dan akan dimasukkan kedalam daftar pemasukan. Untuk menampilkan detail item pemasukan, sistem akan mengarahkan ke halaman detail dengan data yang sudah dicocokkan dari database, admin dapat mengubah, menghapus atau kembali ke daftar pemasukan.

Pengelolaan katalog produk dilakukan oleh admin dengan mengakses menu katalog produk, daftar produk akan ditampilkan dengan foto masing-masing produk. Admin dapat menambahkan produk baru dengan mengklik tombol tambah produk, mengisi form produk baru dan menyimpan produk baru.

Admin dapat melihat detail produk dengan mengklik tombol detail produk, didalam detail produk, admin dapat mengubah detail produk dan akan diarahkan ke form edit produk, produk diubah. Admin menghapus produk, sistem memberikan konfirmasi penghapusan, produk dihapus. User biasa dapat mengakses produk dengan detail yang terbatas dan tidak dapat mengubah, menambahkan, menghapus data produk.

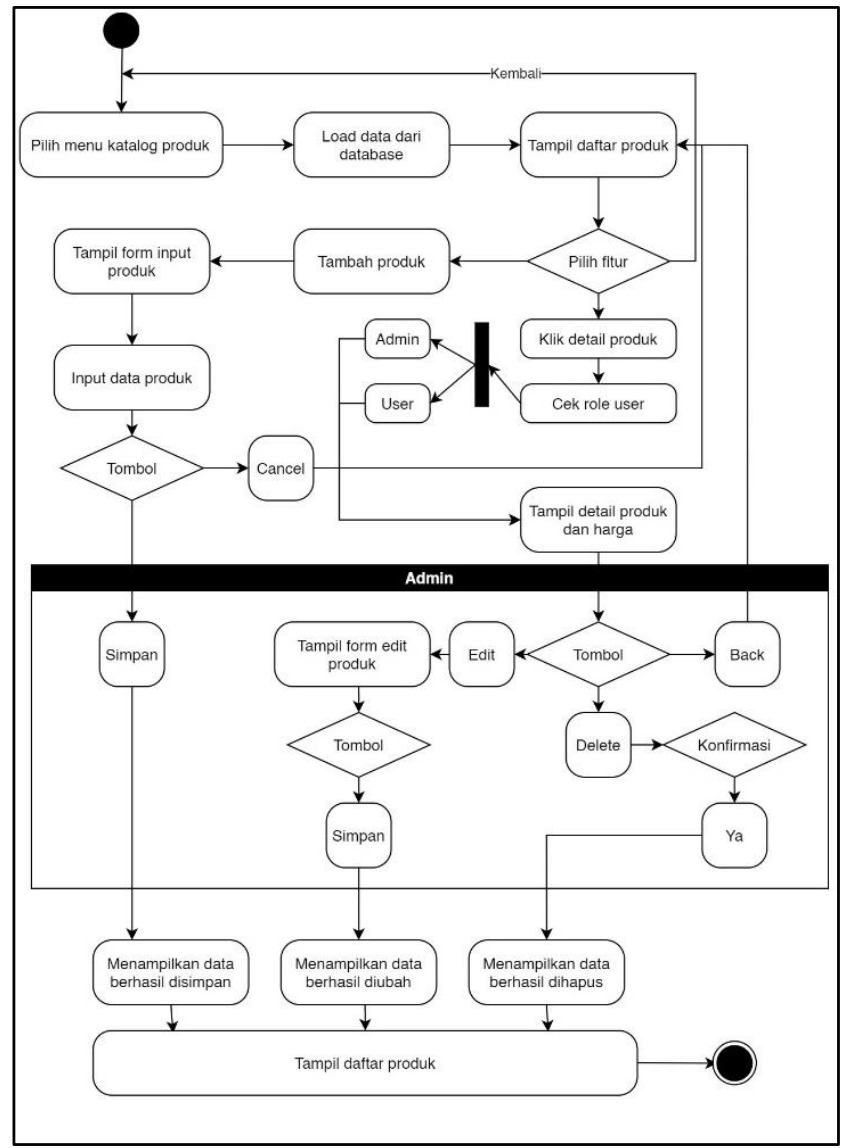

Gambar 5. Activity Diagram Pengelolaan Katalog Produk

Untuk pengelolaan data vendor dilakukan oleh admin, admin memilih menu vendor, dan daftar vendor akan ditampilkan. Admin dapat menambahkan data vendor baru dengan mengklik tombol tambah vendor, form input vendor baru akan ditampilkan, data dimasukkan, data vendor baru disimpan.

Admin dapat melihat detail data vendor dengan mengklik kartu vendor, detail vendor akan tampil. Admin merubah data vendor dengan mengklik tombol edit, form edit ditampilkan, data vendor diubah. Admin dapat menghapus data vendor, konfirmasi menghapus, data vendor dihapus dan admin akan dikembalikan ke halaman daftar vendor. 


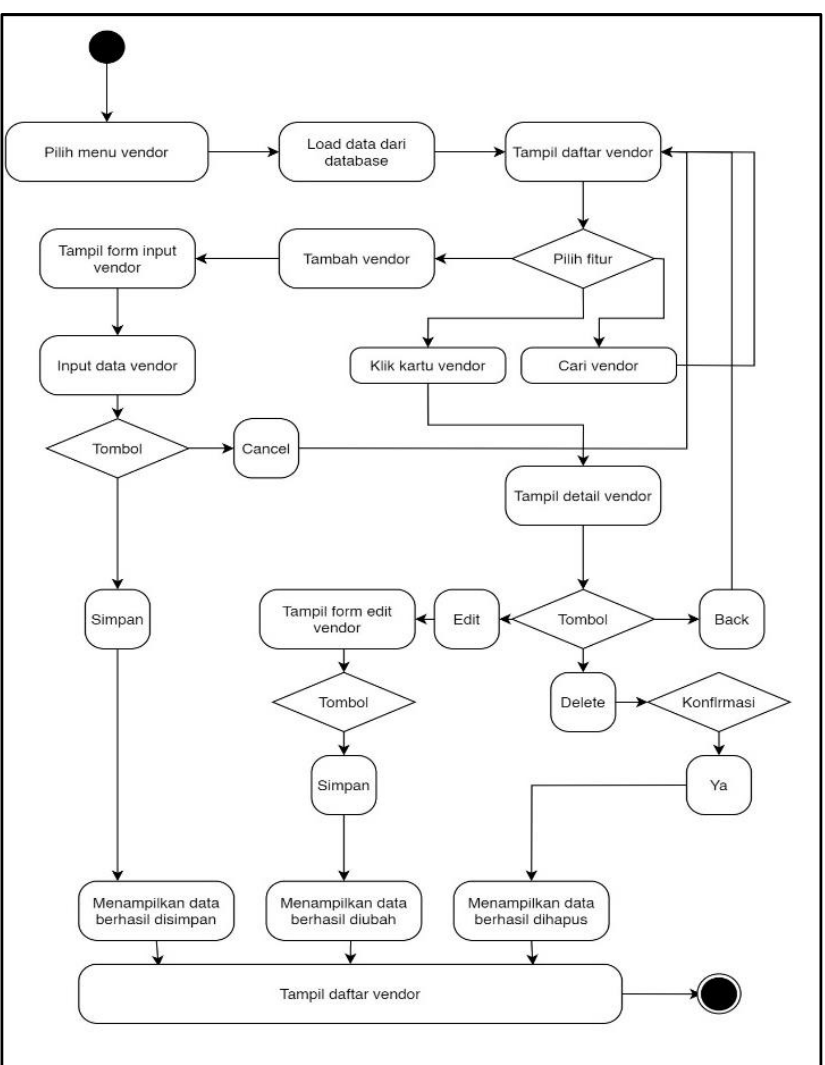

Gambar 6. Activity Diagram Pengelolaan Vendor

Berikut merupakan diagram class untuk menguraikan beberapa class serta komponen- komponen yang ada didalam sistem aplikasi pendataan Cloversy.id serta relasi- relasi yang ada antara komponen satu dengan lainnya. Diagram class berikut menunjukkan property dan method dari tiap-tiap komponen yang terdapat dalam sistem (Gambar 8).

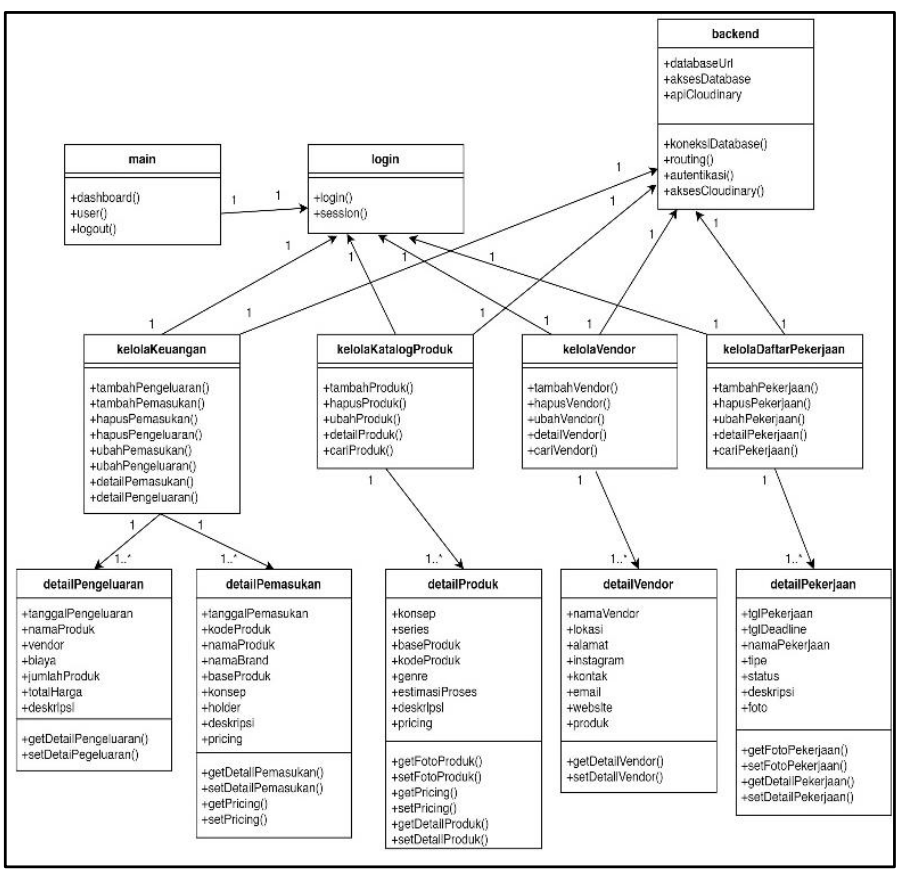

Gambar 7. Class Diagram
Kemudian dalam konteks rancangan halaman- halaman yang ada pada aplikasi pendataan Cloversy.id. Terdapat halaman pengelolaan keuangan dengan fungsi untuk menampilkan data transaksi. Sistem aplikasi pendatatan Cloversy.id dapat memastikan bahwa user yang dapat menggunakan aplikasi dan mengelola data hanyalah user yang sudah diberikan izin.

Sistem melakukan pengelolaan cookie dan session agar user dapat login tanpa harus selalu memasukkan hak akses, penyimpanan status autentikasi untuk menampilkan konten dinamis didalam penggunaan aplikasi. Session menjalankan peran penting dalam memberi akses dan memastikan pengguna benar- benar terautentikasi dengan menyimpan kombinasi kredensial hak akses pada server (session collections) dan pada browser pengguna (cookies) [20].

3) Coding (Pengkodean)

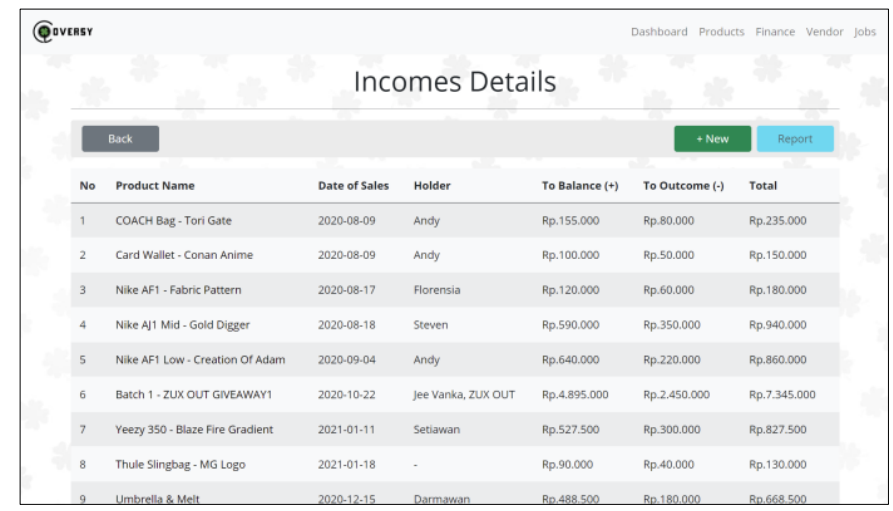

Gambar 8. Halaman Transaksi Aplikasi Pendataan Cloversy.id

Halaman dashboard merupakan halaman awal setelah proses login dan autentikasi berhasil dilakukan. Pada halaman dashboard ini, semua menu akan tampil pada bagian navbar (untuk admin) dan untuk user non-admin menu akan tampil namun lebih terbatas.

Dashboard merupakan komponen yang penting dari aplikasi pendataan Cloversy.id, karena pada bagian dashboard, admin atau pengguna dapat melakukan akses ke berbagai fitur, memantau secara keseluruhan baik dari saldo kas, produk, dan lainnya. Pada bagian dashboard, admin juga dapat melihat data penting seperti kas saat ini, jumlah produk atau desain, jumlah produk terjual.

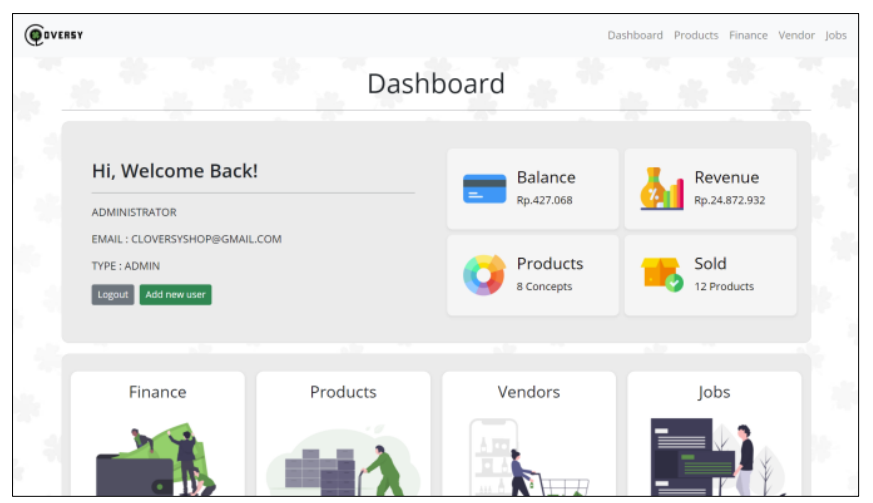

Gambar 9. Halaman Dashboard 
Pada halaman daftar pekerjaan, admin dapat menambahkan pekerjaan baru, mencari, atau mengakses detail pekerjaan dan mengubah dan menghapus data pekerjaan. User non-admin hanya dapat mengakses detail pekerjaan. User non-admin tidak dapat mengubah atau menghapus data pekerjaan.

Data pekerjaan ditampilkan dengan kartu dengan nama pekerjaan, gambar, tanggal pekerjaan ditambahkan, jenis pekerjaan dan status pekerjaan sebagai kontennya. Dengan daftar tersebut, tim Cloversy.id dapat melakukan pemantauan terkait pekerjaan yang sedang berlangsung dan detail dari pekerjaan yang ada.

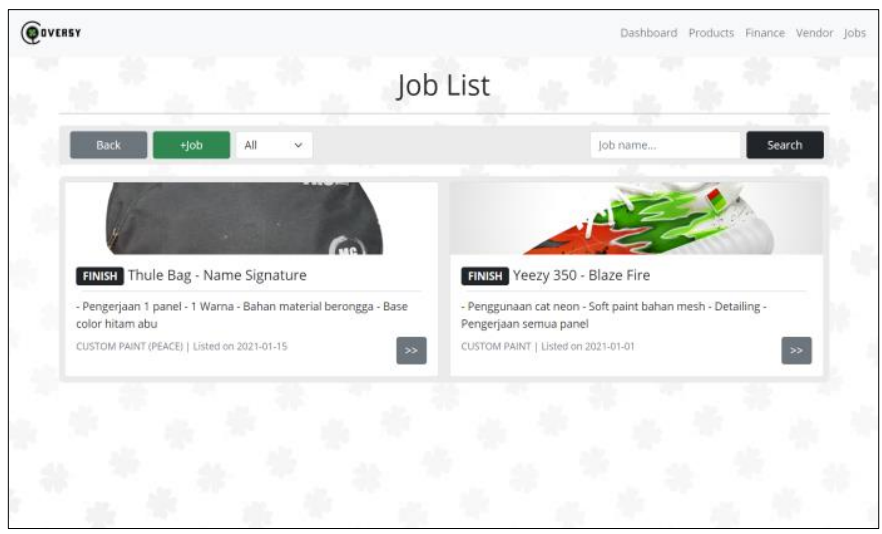

Gambar 10. Halaman Daftar Pekerjaan

Pada halaman katalog produk, digunakan untuk menyimpan berbagai produk Cloversy.id, baik admin maupun user dapat mengakses katalog produk ini. Foto produk disimpan melalui penggunaan cloud storage yang disediakan oleh Cloudinary,

Cloudinary adalah platform yang menyediakan layanan cloud untuk image, download, dan CDN (Content Delivery Network) [21]. Penggunaan cloud storage untuk menyimpan berbagai gambar dan asset website dapat memudahkan dalam memperoleh gambar dan menghemat tempat penyimpanan pada server hosting. Halaman daftar produk ditampilkan pada Gambar 12.

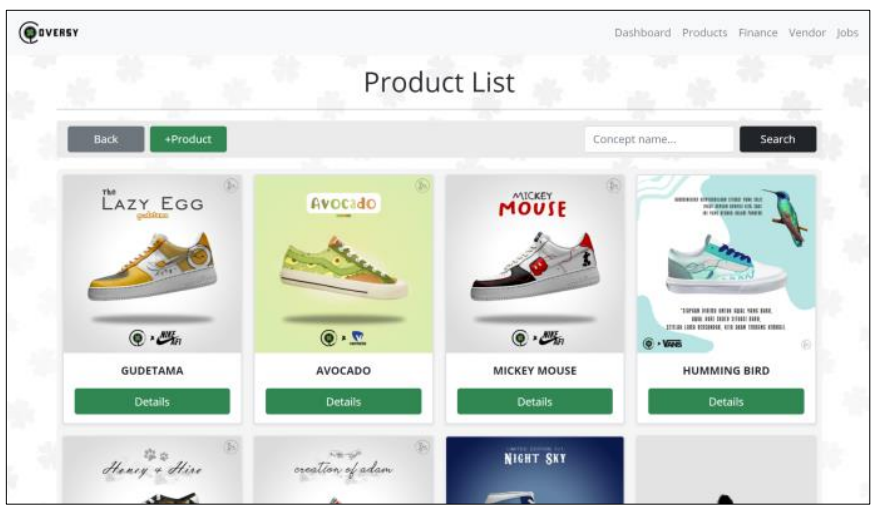

Gambar 11. Halaman Katalog Produk

\section{4) Testing (Pengujian)}

Pengujian aplikasi pendataan Cloversy.id dilakukan menggunakan pengujian Black Box dengan cara menjalankan aplikasi dengan tujuan untuk menemukan kesalahan serta memeriksa apakah sistem dapat berjalan dengan baik sesuai dengan kebutuhan [22]. Skema pengujian yang dilakukan pada penelitian ini adalah pengujian proses pengelolaan keuangan, pengelolaan produk. Pengujian Black Box yang dilakukan diantaranya menggunakan teknik:

\section{a) Equivalence Partitioning}

Pengujian masukan pada setiap form pada pengelolaan pemasukan, pengeluaran, katalog produk, vendor, dan daftar pekerjaan. Pengujian dilakukan dengan masukan data valid dan data yang tidak valid, hasil pengujian form dapat berfungsi dengan baik dan data tidak valid dapat dideteksi oleh validasi form.

\section{b) Feature Test}

Pengujian fitur dilakukan secara menyeluruh mencakup fitur login, logout, kelola keuangan, produk, vendor, dan daftar pekerjaan. Fitur berfungsi dengan baik dan aplikasi dapat menampilkan dan menyimpan informasi dengan tepat.

Pengujian dari segi keamanan juga dilakukan terkait fitur login dan logout, pengujian keamanan dilakukan dengan percobaan melakukan cross site scripting (xss) dan noSQL Injection. Cross site scripting adalah salah satu kejahatan terhadap keamanan aplikasi melalui masukan pada browser yang dilakukan dengan tujuan mengambil alih kendali dari browser pengguna, mengambil kerahasiaan data, penyisipan file [23]. Pengujian dilakukan langsung menggunakan aplikasi pendataan Cloversy.id dari sisi client-side serta menggunakan aplikasi Postman untuk mengakses routing tanpa melalui clientside.

Dari semua hasil pengujian Black Box tersebut, terlihat bahwa semua pengujian telah sesuai dengan hasil yang diharapkan. Keterbatasan dari penelitian ini adalah tidak dapat mencakup seluruh aspek dalam pengembangan aplikasi seperti kurangnya mekanisme dalam konteks keamanan (sistem keamanan ada diterapkan, tapi tidak benar- benar ditonjolkan).

\section{KESIMPULAN}

Aplikasi pendataan Cloversy.id dapat berjalan sesuai dengan fungsinya untuk melakukan pengelolaan keuangan, produk, vendor, dan daftar pekerjaan. Dengan dibuatnya aplikasi ini, tim Cloversy.id dapat melakukan pendataan secara online dari berbagai perangkat. Aplikasi ini membantu tim Cloversy.id dalam melakukan pendataan terhadap arus kas dari pemasukan dan pengeluaran sehingga mempermudah dalam melakukan akses histori keuangan. Aplikasi ini memungkinkan katalog produk Cloversy.id yang sebelumnya disusun hanya menggunakan sistem folder, sekarang dapat disimpan dan diakses secara lengkap terkait foto, harga, detail produk baik oleh tim Cloversy.id atau reseller. Fitur pengelolaan pekerjaan juga memudahkan bagi tim Cloversy.id untuk melakukan monitoring terhadap detail pekerjaan, deadline dan bantuan visual berupa foto untuk memperjelas desain. Dengan semua fitur yang ada didalam aplikasi ini, tim Cloversy.id memiliki sistem pendataan yang baik dan dapat melayani konsumen dengan lebih cepat dan efisien. 


\section{SARAN}

Untuk penelitian selanjutya dapat diperluas dengan menambahkan proses yang melibatkan konsumen secara langsung, memberikan tempat bagi konsumen untuk dapat melakukan tracking secara online terhadap proses pengerjaan sehingga dapat menjamin dan meningkatkan kepuasan konsumen. Pengembangan aplikasi ini dapat dilanjutkan kedalam tahap optimalisasi seperti penerapan pagination untuk mencegah tampilan sistem terlalu padat karena data yang terlalu banyak. Selain itu, dapat dikembangkan fitur tambahan seperti push notification agar interaksi dapat lebih dinamis.

\section{DAFTAR PUSTAKA}

[1] Rahmawati, "Sistem Informasi Inventory Stock Barang Pada CV. Artha," J. Chem. Inf. Model., vol. 21, no. 2, 2017.

[2] T. Sutabri, Analisis Sistem Informasi. Jakarta: Penerbit Andi Yogyakarta.

[3] T. T. Loveri, "SISTEM INFORMASI APLIKASI PENGELOLAAN TRANSAKSI KEUANGAN DAN PENDATAAN KONSUMEN PADA CV. PUPLAS," J. Sains dan Inform., vol. 4, no. 2, 2018, doi: 10.22216/jsi.v4i2.3584.

[4] D. W. Kuncoro, "Analisis Dan Perancangan Sistem Kasir Dan Pendataan Stok Barang Pada Tata Distro Pacitan," J. Speed - Sentra Penelit. Eng. dan Edukasi, vol. 7, no. 1, 2015.

[5] P. Noviandhiny, H. Nasution, and E. Esyudha Pratama, "Rancang Bangun Aplikasi Penjualan dan Pembelian Berbasis Web Pada Apotek Neofarma Sanggau," J. Sist. dan Teknol. Inf., vol. 6, no. 3, 2018, doi: 10.26418/justin.v6i3.25770.

[6] F. R. Arfianto and F. Nugrahanti, "Rancang Bangun Aplikasi Penjualan Perumahan Berbasis Web Pada Cv. Grand Permata Residence Magetan,” Semin. Nas. Teknol. Inf. dan Komun., vol. 1, no. $2017,2018$.

[7] S. Susanti, E. Junianto, and R. Rachman, "Implementasi Framework Laravel Pada Aplikasi Pengolah Nilai Akademik Berbasis Web," $J$. Inform. UBSI, 2017, doi: 10.31311/JI.V4I1.1562.

[8] O. I. - AMIK BSI Bekasi and G. B. A. L. - AMIK BSI Bekasi, "Metode Rapid Application Development (RAD) pada Perancangan Website Inventory PT. SARANA ABADI MAKMUR BERSAMA (S.A.M.B) JAKARTA," Evolusi J. Sains dan Manaj., vol. 6, no. 2, 2018, doi: 10.31294/evolusi.v6i2.4414.

[9] M. Noor and R. Sari, "SISTEM INFORMASI KARTU INVENTARIS BARANG BERBASIS WEB DI PERTAMBANGAN DAN ENERGI KABUPATEN TANAH LAUT," J. sains dan Inform., 2017.
[10] N. Fikri, "APLIKASI BERBASIS WEB UNTUK PENDATAAN MASUK DAN KELUAR BARANG DAGANGAN PADA UMKM STUDI KASUS: CV. TIARA CELL (COUNTER GADGET DAN AKSESORIS)," J. Ilmu Tek. dan Komput., vol. 3, no. 2, 2019, doi: 10.22441/jitkom.2020.v3.i2.003.

[11] M. Y. Simargolang and N. Nasution, "Aplikasi Pelayanan Jasa Laundry Berbasis WEB (Studi Kasus : Pelangi Laundry Kisaran)," $J$. Teknol. Inf., vol. 2, no. 1, 2018, doi: 10.36294/jurti.v2i1.402.

[12] F. Marisa and T. G. Yuarita, "PERANCANGAN APLIKASI POINT OF SALES (POS) BERBASIS WEB MENGGUNAKAN METODE SIKLUS HIDUP PENGEMBANGAN SISTEM," J. Teknol. dan Manaj. Inform., vol. 3, no. 2, 2017, doi: 10.26905/jtmi.v3i2.1514.

[13] D. Prasanti, D. Sri, and S. Indriani, "Pengembangan Teknologi Informasi Dan Komunikasi Dalam Sistem E-Health Alodokter.Com the Use of Information and Communication Technology in E-Health System Alodokter.Com," J. Sosioteknologi, vol. 17, no. 1, 2018.

[14] F. Fatoni and D. Irawan, "Implementasi Metode Extreme Programming dalam Pengembangan Sistem Informasi Izin Produk Makanan," J. Sisfokom (Sistem Inf. dan Komputer), vol. 8, no. 2, 2019, doi: 10.32736/sisfokom.v8i2.679.

[15] R. S. Pressman and B. R. Maxim, Software Engineering: A Practitioner's Approach, Eighth Edition, vol. 66. 2015.

[16] A. Rohman, I. Yatini, J. R. Janti, and K. J. Yogyakarta, “Aplikasi Asisten Praktikum Menggunakan Node.js dan Database MongoDB (Studi Kasus Lab STMIK AKAKOM)," 2016.

[17] S. Hoque, Full-Stack React Projects, Second Edi. Birmingham: Packt Publishing Ltd, 2020.

[18] V. Subramanian, Pro MERN Stack, Full Stack Web App Development with Mongo, Express, React, and Node. 2019.

[19] C. Arief, "Studi Fitur dan Implementasi Cloud Based DBMS MongoDB Atlas," Universitas Katolik Parahyangan, 2019.

[20] I. Gita Anugrah and M. Aldi Rifai Imam Fakhruddin, "Development Authentication and Authorization Systems of Multi Information Systems Based REst API and Auth Token," Innov. Res. J., vol. 1, no. 2, 2020.

[21] A. Ayuningtyas and A. R. Pramudi, "UNDANGAN PAPERLESS BERBASIS CLOUD COMPUTING DENGAN MEMANFAATKAN CLOUDINARY," Compiler, vol. 6, no. 1, 2017, doi: 10.28989/compiler.v6i1.195.

[22] T. Hidayat and M. Muttaqin, "Pengujian Sistem Informasi Pendaftaran dan Pembayaran Wisuda Online menggunakan Black Box Testing dengan Metode Equivalence Partitioning dan Boundary Value Analysis," J. Tek. Inform. UNIS JUTIS, vol. 6, no. 1, 2018.

[23] Y. Yulianingsih, "Melindungi Aplikasi dari Serangan Cross Site Scripting dengan Metode Metacharacter," J. Nas. Teknol. dan Sist. Inf., vol. 3, no. 1, 2017, doi: 10.25077/teknosi.v3i1.2017.83-88. 